\title{
Phytoextraction Potential of Arsenic And Cadmium And Response of Rhizosphere Microbial Community By Intercropping With Two Types of Hyperaccumulators
}

\author{
Xiaohui Wang \\ Central South University \\ Cong Zhou \\ Central South University \\ Xiyuan Xiao ( $\nabla$ xiaoxy@csu.edu.cn ) \\ Central South University \\ Zhaohui Guo \\ Central South University \\ Chi Peng \\ Central South University \\ Xiaoyan Wang \\ Central South University
}

\section{Research Article}

Keywords: Intercropping, As and Cd phytoextraction, rhizosphere bacterial microbiota

Posted Date: November 3rd, 2021

DOI: https://doi.org/10.21203/rs.3.rs-888645/v1

License: @) (i) This work is licensed under a Creative Commons Attribution 4.0 International License. Read Full License 


\section{Abstract}

Intercropping with hyperaccumulators/accumulators is a promising alternative to enhance phytoextraction of heavy metal(loid)s in contaminated soil. In this research, a pot experiment was conducted to evaluate the influences of intercropping As hyperaccumulator Pteris vittata L. with Cd hyperaccumulator Sedum alfredii Hance or accumulator Hylotelephium spectabile (Boreau) $\mathrm{H}$. Ohba on the plant growth, As and $\mathrm{Cd}$ phytoextraction, and rhizosphere bacterial microbiota. The results indicated that intercropping can promote the growth of plants. The total biomass of $P$. vittata, $S$. alfredii and $H$. spectabile in intercropping systems was significantly improved by $19.9 \%-34.1 \%, 16.8 \%$ and $11.5 \%$, respectively in comparison with corresponding plant monoculture. The As content in rhizoid and frond of $P$. vittata when intercropped with $S$. alfredii was increased by $28.3 \%$ and $19.0 \%(P<0.05)$, respectively as compared with $P$. vittata monoculture, and this treatment acquired the maximum As and Cd accumulation with 2032 and $397 \mu \mathrm{g} \bullet$ pot $^{-1}$, respectively. Intercropping enhanced the soil bacterial community diversity. The genera of Lysobacter in S. alfredii rhizosphere soil and Massilia in P. vittata rhizosphere soil had higher abundance in the intercropping system of $P$. vittata and $S$. alfredii. And the significantly positive correlation relationships were found between Massilia, Lysobacter and plant As content, and Arthrobacter with plant Cd content, indicating that they may play important roles in As and Cd phytoextraction. The results suggested that intercropping $P$. vittata with $S$. alfredii could be a potential strategy for phytoextraction of As and Cd from co-contaminated soil.

\section{Introduction}

Soil polluted with heavy metals (metalloids) has been one of the global environmental challenges due to their persistence and toxicity to animals, inhibition to the growth of plants and microorganisms in the soil environment (Antoniadis et al., 2017). There was more than 10 million $\mathrm{km}^{2}$ contaminated soil in the world, and about 1.0 million $\mathrm{km}^{2}$ contaminated soil with approximately $80 \%$ of those caused by heavy metal(loid)s has been reported in China (He et al., 2015). Among those heavy metals, high concentrations of cadmium (Cd) and arsenic (As) in soils are frequently reported (Xiao et al., 2008; Huang et al., 2016). China nationwide surveys have been shown that $C d$ and As ranks the first (7.0\%) and third (2.7\%) in the percentage of soil samples overrunning the Ministry of Environmental Protection limit among the 8 heavy-metal elements $(\mathrm{Ni}, \mathrm{Hg}, \mathrm{Cu}, \mathrm{Pb}, \mathrm{Zn}$, As, Cd, Cr) (Zhao et al., 2015). A document retrieval database with heavy metal contents in soils obtained from 1443 industrial and agricultural sites in China has been reported that As and Cd were determined as the priority control pollutants (Yang et al., 2018). Arsenic and Cd have been the category one carcinogens claimed by the World Health Organization (WHO, 2017). Moreover, agricultural soil polluted with As and Cd damages human health through the food chain (Mu et al., 2019; Kumar et al., 2019). Thus, it is urgent to find an efficient and cost-effective technique for the remediation of As and Cd co-contaminated soil.

Phytoextraction utilizes the hyperaccumulators with the accumulation ability for high content of metal(loid)s in aboveground part to remove pollutants in soil and has been one of the most widespread and alternative phytoremediation techniques (Patra et al., 2020). There are 721 metal/metalloid hyperaccumulator species in the global database with the global records in July 2017 (Reeves et al., 2017). Some heavy metal accumulators with high shoot biomass such as Linum usitatissimum L. and Hylotelephium spectabile (Boreau) H. Ohba were used to remediate soil (Yang et al., 2018; Guo et al., 2020). However, the majority of hyperaccumulators and accumulators were mainly limited to choose one or two specific metals, which limits their application in phytoremediation of multi-metal(loid)s polluted soils (January et al., 2008). So far, there was little information on As and Cd co-hyperaccumulators, which was a great challenge for phytoextraction of As and Cd in co-contaminated soil due to their different opposite geochemical behavior.

Intercropping, one of the most representative agronomical practice, is helpful for the improvement of the structure of planting system and the efficiency of resource utilization (Bedoussac et al., 2015). Some researchers have reported that intercropping hyperaccumulators with other plant species could improve the tolerance of plants to heavy metal(loid)s and/or enhance the comprehensive phytoextraction efficiency (Desjardins et al., 2018). For example, the intercropping of hyperaccumulator Sedum plumbizincicola and moso bamboo (Bian et al., 2017), Sedum alfredii and oilseed rape (Cao et al., 2020), Pteris vittata L. and Morus alba L. (mulberry) (Wan et al., 2017) could simultaneously remediate soil and obtain safe crop products. The higher accumulation of different heavy metals by intercropping with diverse plant species was owing to the effect of root exudates 
and soil microorganisms on metal speciation and bioavailability in rhizosphere soil (Tang et al., 2017; Yu et al., 2016; Li et al., 2019). In addition, there were positive relationship between soil microorganism response and intercropping plants. For instance, the toxicity of heavy metals to soil microbial community structures could be efficiently alleviated by intercropping herbs with woody plants for phytoremediation of contaminated soil compared with monoculture (Zeng et al., 2019a). Cao et al. (2020) have founded that the variations of bacterial community in rhizosphere soil were very important for Cd phytoextraction in the intercropping system of Sedum alfredii and oilseed rape. Hence, when soils contaminated with multiple metals are remediated, intercropping with two or more different heavy metal(loid)s hyperaccumulators/accumulators might be an effective measure to solve this problem (Lin et al., 2018).

Arsenic hyperaccumulator $P$. vittata L. has been widely applied for the phytoextraction of As-contaminated soil (Wan et al., 2020). S. alfredii Hance was a $\mathrm{Cd} / \mathrm{Zn}$ hyperaccumulator and was also used for phytoextraction of multiple-metal ( $\mathrm{Cd}, \mathrm{Pb}$ and Zn) soils (Yang et al., 2004; Liang et al., 2019). Hylotelephium spectabile (Boreau) H. Ohba, a potential Cd accumulator with high shoot biomass, could make up for a relatively low Cd content in aboveground parts (Zhou et al., 2020; Guo et al., 2020). Several studies about $P$. vittata or $S$. alfredii intercropping with other plant species to remediate only As or Cd contaminated soils have been reported (Wan et al., 2017; Cao et al., 2020). However, there is scarce information about the simultaneous phytoextraction As and Cd from co-contaminated soil by intercropping of As hyperaccumulator and Cd hyperaccumulator. Also, the influences of intercropping on rhizosphere microbial response and their effects on plant performance and heavy metal accumulation still remain unknown (Cao et al., 2020). In this study, a greenhouse experiment was conducted to study the phytoextraction potential of As and $\mathrm{Cd}$ in co-contaminated soil by intercropping $P$. vittata with $S$. alfredii/ $H$. spectabile. The aims were to 1) investigate the impact of intercropping on plant biomass and physiological response; 2) compare the As and $\mathrm{Cd}$ content and accumulation in plants under the different intercropping systems; and 3) determine the changes in rhizosphere microflora and explore the correlation between response of rhizosphere soil microorganisms and heavy metal removal efficiency. The outcome in this study may helpful for establishing hyperaccumulator/accumulator intercropping systems to remediate soil co-polluted by As and Cd.

\section{Materials And Methods}

\subsection{Soil sample and plant seedlings}

The tested soils were sampled from a deserted agricultural land of the surface layer $(0-20 \mathrm{~cm})$ near a closed As smelting plant in Changde city of Hunan Province, China. After the scrap and plant residues were removed, the soil samples were air-dried, pestled, and passed through a $5 \mathrm{~mm}$ nylon sieve for pot experiments. The soil physicochemical properties were $\mathrm{pH}$, 8.10; soil organic matter content, $16.6 \mathrm{~g} \bullet \mathrm{kg}^{-1}$; available content of nitrogen $(\mathrm{N})$, phosphorous $(\mathrm{P})$, and potassium (K) with 59.5, 30.0, and $109 \mathrm{mg} \cdot \mathrm{kg}^{-1}$, respectively. The total content of As $\left(410 \mathrm{mg} \cdot \mathrm{kg}^{-1}\right)$ and $\mathrm{Cd}\left(3.0 \mathrm{mg} \cdot \mathrm{kg}^{-1}\right)$ was far higher than the recommended content of As $\left(25 \mathrm{mg} \cdot \mathrm{kg}^{-1}\right)$ and $\mathrm{Cd}\left(0.6 \mathrm{mg} \cdot \mathrm{kg}^{-1}\right)$ listed in the Risk Control Standard for Soil Contamination of Agricultural Land (GB15618-2018) (pH>7.5).

Seedlings of $P$. vittata and $H$. spectabile were acquired from a nursery base in Shimen County, Hunan Province and a nursery base in Hebei Province established by the Institute of Geosciences and Resources of the Chinese Academy of Sciences, respectively. The $S$. alfredii seedlings sampled from Zhejiang Province were planted in the unpolluted farm soil for pot experiments.

\subsection{Experimental design and plant incubation}

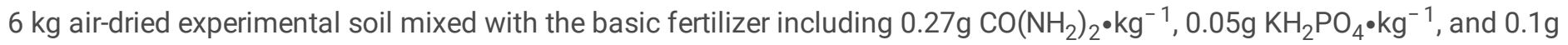
$\mathrm{KNO}_{3} \cdot \mathrm{kg}^{-1}$ soil was placed into a container (30 cm length $\times 22 \mathrm{~cm}$ width $\times 12 \mathrm{~cm}$ height). The soil was sprayed with deionized water to maintain at equilibration with $70 \%$ water-holding capacity for two weeks. Then, the healthy seedlings with uniform size of $P$. vittata, $S$. alfredii, and $H$. spectabile were transplanted into each pot. The intercropping patterns were listed in Table S1, which included: 1) monoculture treatment of P. vittata (PM), S. alfredii (SM), and H. spectabile (HM) with 4 seedlings, respectively; 2) intercropping of 2 P. vittata with 2 S. alfredii seedlings (PS) or 2 H. spectabile seedlings (PH). The unplanning 
soil was used as a control treatment (CK). Each treatment has 4 replicates. The pot experiment was conducted in a greenhouse under the controlled conditions of $14 \mathrm{~h}$ photoperiod with photon flux of $260-350 \mathrm{mmol} \mathrm{m} \mathbf{~}^{-2} \mathrm{~s}^{-1}$ and a day/night temperature of $30^{\circ} \mathrm{C} / 22^{\circ} \mathrm{C}$. Deionized water was added into each pot daily to maintain plant's growth.

After $120 \mathrm{~d}$ cultivation, plants in each pot were harvested and divided into rhizoids and fronds for $P$. vittata, shoots and roots for $S$. alfredii and $H$. spectabile. The plant samples were clean washed and weighed as fresh biomass. Some fresh leaves/pinna (for $P$. vittata) was placed in $4^{\circ} \mathrm{C}$ for the analysis of malondialdehyde (MDA) and soluble protein contents. The rest plant parts were de-enzymized for $30 \mathrm{~min}$ at $105^{\circ} \mathrm{C}$, dried at $65^{\circ} \mathrm{C}$ until a constant weight. The samples were ground and screened by a 1 $\mathrm{mm}$ nylon sieve for further determination. Besides, the rhizosphere soil samples from each pot were collected as described by Wang et al. (2018). The 7 rhizosphere soil samples were recorded as PM, SM and HM (monoculture treatment), PS-P (P. vittata in PS treatment), PS-S (S. alfredii in PS treatment), PH-P (P. vittata in $\mathrm{PH}$ treatment), $\mathrm{PH}-\mathrm{H}$ (H. spectabile in $\mathrm{PH}$ treatment). These soil samples were used for the analysis of $\mathrm{pH}$, available As and $\mathrm{Cd}$ content, and microbial community.

\subsection{Soil and plant sample analysis}

Soil physiochemical properties were measured following the methods of Lu (2000). The content of soluble protein in fresh leaves/pinna was measured using coomassie brilliant blue G-250 and bovine serum albumin, and then counted and presented as $\mathrm{mg} \bullet \mathrm{g}^{-1} \mathrm{FW}$ (fresh weight) (Aitken and Learmonth, 2009). The MDA content was analyzed according to the thiobarbituric acid (TBA) reaction following the method of Velikova et al. (2000).

The plant and soil samples were digested in the acid mixture of $\mathrm{HNO}_{3}: \mathrm{HClO}_{4}(5: 1)$ (Yang et al., 2012) and mixture of $\mathrm{HNO}_{3}-$ $\mathrm{H}_{2} \mathrm{O}_{2}$ (USEPA, 1996) to determine total As and Cd content, respectively. Blank and standard reference materials of plant (GBW07603) and soil (GBW-08303) were used to assess the quality control of samples analysis. The available As and Cd content in soil was extracted using $\mathrm{NaHCO}_{3}$ solution (Woolson et al., 1971) and the diethylene-triaminepenta acetic acid (DTPA) solution (Lindsay and Norvell, 1978), respectively. The Cd and As contents in digested and extracted solutions were measured through the inductive coupled plasma-optical emission spectrometer (ICP-OES, Thermo, USA) and hydrogen generation-atomic fluorescence spectrometer (AFS-2202E, Haiguang Instrument Company of Beijing, China), respectively.

The DNA extraction from the rhizosphere soil samples was performed by the method of Moffett et al. (2003) and detected using $1.0 \%$ agarose gel electrophoresis. The V3-V4 regions of the bacterial 16S rRNA gene were amplified with the polymerase chain reaction, which was performed using the 341F/806R primer set. All PCR products were recovered and purified with $2 \%$ agarose gel and AxyPrepDNA Gel Extraction Kit (Thermo Scientific, USA), eluted with Tris-HCl buffer solution, and detected with QuantiFluor $^{\text {TM }}$-ST (Promega, USA) blue fluorescence quantitative system. Purified amplicons were sequenced according to an Illumina platform (Illumina Inc., San Diego, CA, USA) at Novogene Co., Ltd, Beijing, China.

\subsection{Statistical analysis}

The translocation factor (TF) of As and Cd in plant was counted as TF = As or Cd content in shoots(fronds)/As or Cd content in root (rhizoid) (Liang et al., 2019). The As and Cd phytoextraction efficiency was described as the plant metal accumulations, which are based on the biomass of root (rhizoid) and shoot (frond) multiplied by As and Cd content in corresponding plant part. The data were analyzed by Microsoft Excel 2016 and shown as the mean values \pm standard deviations. All statistical analyses were conducted using SPSS 18.0 software. One-way analysis of variance (ANOVA) with Duncan's test at the significance level of $P<0.05$ was applied for the comparison of differences in plant growth, As and Cd uptake among different intercropping treatments.

The Majorbio cloud platform was used for online data analysis of diversity gene sequencing. Venn diagram was drawn to highlight similarities between the monoculture and intercropping treatments. Community bar plot was drawn to show the relative abundance of microorganisms. Heat map analysis was performed using Heml 1.0. Redundancy analysis (RDA) was applied to analyze the correlation between the bacterial communities and selected soil environmental factors or the phytoremediation parameters, various R packages (http://www.r-project.org). 


\section{Results And Discussion}

\subsection{Plant growth, MDA, and soluble protein content in leaf / pinna}

The plant growth was positively affected by intercropping treatment (Fig. 1). Compared with monoculture treatment (PM), the rhizoid and frond biomass of $P$. vittata was enhanced by $20.1 \%$ and $13.2 \%$ for PS treatment, $34.1 \%$ and $24.3 \%$ for PH treatment, consequently, the total biomass was significantly increased by $19.9 \%$ and $34.1 \%$, respectively $(P<0.05)$. The shoot biomass of S. alfredii in PS treatment was significantly improved by $21.1 \%$, and that of $H$. spectabile from $\mathrm{PH}$ treatment improved by $11.5 \%$ as compared with SM and $\mathrm{HM}$, respectively $(P<0.05)$. This is consistent with previous results that intercropping could protect neighboring companion plants and enhance plant growing on soil contaminated with heavy metals (Wan et al., 2017; Zeng et al., 2019b; Cao et al., 2020). This may be contributed to the improvement of the rhizosphere environment where the soil As efficiently extracted by P. vittata (Wan et al., 2017). Hong et al (2017) confirmed that different plant species show different temporal and spatial resource requirements, so intercropping can obtain essential growth resources more conveniently than monoculture plant.

The content of MDA in pinna of $P$. vittata from the intercropping system of PS and PH was significantly dropped by $15.3 \%$ and 17.3\% $(P<0.05)$ compared with PM, respectively (Table 1$)$. The result was in consistent with former findings that intercropping with Solanum nigrum or Solanum photeinocarpum significantly decreased the MDA content in eggplant in comparison to monoculture (Tang et al., 2017). The reason may be related to that intercropping alleviates the oxidative stress of metal(loid)s to decrease the degree of leaf lipid peroxidation and promote the $P$. vittata growth (Du et al., 2020). The soluble protein is beneficial to reduce water loss and maintain the main function of cellular membranes stressed by heavy metals (Pan et al., 2018). Intercropping treatments of PS and PH significantly increased the soluble protein content of $P$. vittata compared with PM $(P<0.05)$ (Table 1), which was consistent with the result of higher $P$. vittata biomass from the intercropping system (Fig. 1). The difference in the leaf MDA and protein content of $S$. alfredii and $H$. spectabile between intercropping and monoculture treatment was not significant, indicating that intercropping has no obvious influence on their physiological response.

\subsection{Arsenic and Cd uptake by plants}

\subsubsection{Uptake and transport of As and Cd}

The As content in rhizoid and frond of $P$. vittata from intercropping treatments was significantly increased by $10.9 \sim 28.3 \%(P<$ $0.05)$ in contrast with PM, and the PS treatment showed the highest As content in rhizoid $\left(245 \mathrm{mg} \cdot \mathrm{kg}^{-1}\right)$ and frond (1339 $\mathrm{mg} \cdot \mathrm{kg}^{-1}$ ) of $P$. vittata. The Cd content in root and shoot of $S$. alfredii in PS treatment was also significantly enhanced by $13.3 \%$ and $25.2 \%$ in comparison to monoculture, respectively $(P<0.05)$ (Table 2$)$. Similar studies have been confirmed that As content in $P$. vittata rhizoid was significantly improved when intercropping with Morus alba and Broussonetia papyrifera L. (Wan and Lei, 2018; Zeng et al., 2019b), and Cd content in S. alfredii intercropped with pakchoi was significantly improved (Ma et al., 2020). These results may be due to the interactions of root exudates which increased the heavy metal phytoavailability in rhizosphere soil (Yang et al., 2006). Unfortunately, the content of Cd in P. vittata frond and that of As in S. alfredii shoot was very low with the maximum value of $2.00 \mathrm{mg} \cdot \mathrm{kg}^{-1}$ and $19.0 \mathrm{mg} \cdot \mathrm{kg}^{-1}$, respectively. This may be related to that most hyperaccumulators strongly accumulate specific metals (Mahar et al., 2016). The difference in the $\mathrm{TF}_{\text {shoot }}$ value of As for $P$. vittata and $\mathrm{Cd}$ for $S$. alfredii between intercropping and corresponding monoculture treatment was not significant. The content of $\mathrm{Cd}$ in root and shoot of $\mathrm{H}$. spectabile from intercropping treatment were sightly decreased, while shoot As content was significantly increased compared with $\mathrm{HM}$ (Table 2). Though the content of $\mathrm{Cd}$ and As in $\mathrm{H}$. spectabile was low, the $\mathrm{TF}_{\text {shoot }}$ value of $\mathrm{Cd}$ was high than 1.0, suggesting that it was effective in $\mathrm{Cd}$ uptake. Our previous study has shown that the maximum Cd content in shoots of $H$. spectabile grown in $5 \mathrm{mgCd} \cdot \mathrm{L}^{-1}$ solution reached up to $603 \mathrm{mg} / \mathrm{kg}$ with the $\mathrm{TF}_{\text {shoot }}$ value of 5.62 (Zhou et al., 2020). This may be owing to low soil Cd content in this study (Yang et al., 2018).

\subsubsection{Arsenic and Cd accumulation in plants}

The As accumulation in fronds of $P$. vittata was significantly enhanced by $27.5 \%$ and $23.4 \%(P<0.05)$ after intercropping with $S$. alfredii and $H$. spectabile compared with PM, respectively (Table 3). Similarly, the Cd accumulation in S. alfredii from PS 
treatment was significantly increased by $14.6 \%(P<0.05)$ in comparison to monoculture. Previous studies also have been reported that intercropping can enhance As accumulation in $P$. vittata intercropped with wood species of Morus alba L. or Broussonetia papyrifera L. (Zeng et al., 2019b). Cao et al. (2020) have demonstrated that co-planting with oilseed rape can improve $C d$ phytoextraction of $S$. alfredii due to reducing intra-species competition for nutrients and water. The As accumulation of $H$. spectabile from $\mathrm{PH}$ treatment was significantly higher than monoculture $(P<0.05)$. It is possible that more root exudates (organic acids) secreted between intercropped plants, which could increase the phytoavailable As and Cd contents in rhizosphere soil and promote heavy metal extraction by corresponding plant (Kim et al., 2013, Li et al., 2019). Generally, the As accumulation from PS and PH treatments were close with 2065 and $1988 \mu \mathrm{g}^{\circ} \operatorname{pot}^{-1}$, respectively, and the Cd accumulation for PS $\left(397 \mu \mathrm{g} \cdot\right.$ pot $\left.^{-1}\right)$ was far higher than that from PH $\left(19.0 \mu \mathrm{g} \bullet\right.$ pot $\left.^{-1}\right)$ treatment, suggesting that the Cd removal was more effective when $P$. vittata intercropped with $S$. alfredii than $H$. spectabile. Thus, intercropping of $P$. vittata and $S$. alfredii may be more effective in simultaneous phytoextraction As and $\mathrm{Cd}$ in co-contaminated soil.

\subsection{Soil pH, available contents of As and Cd after remediation}

The rhizosphere soil pH was slightly varied from 7.84 to 7.99 (Fig. 2), which was coincided with previous findings that soil pH under the intercropping of $P$. vittata and castor bean slightly altered (Yang et al., 2017), suggesting that acidification is not the mobilization mechanism of soil metals in present study (Liang et al., 2019). The available As content in PS-S rhizosphere soil was significantly higher than that from unplanted soil (CK) and other planting treatments except for PS-P and PH-H rhizosphere soil. The available Cd content in SM and PS-P rhizosphere soil was higher than that in HM, PH-P and PH-H rhizosphere soil, indicating that intercropping $P$. vittata and $S$. alfredii could enhance As and Cd mobility in soil (Fig. 2). Organic acids secreted by hyperaccumulators could facilitate the transformation of heavy metals to an exchangeable fraction thus indirectly resulting in high phytoremediation efficiency (Zu et al., 2020). Previous researches have been confirmed that organic acids like oxalic acid as a predominant root exudate of both $S$. alfredii and $P$. vittata could trigger soil As and Cd availability and enhance uptake by plant (Tao et al., 2016; Das et al., 2017; Liang et al., 2021). Also, Xia et al. (2018) have reported that the secretion components in soil from intercropping systems with Conyzacanadensis, Cardaminehirsuta, and Cerastiumglomeratum are significantly more complex than those from monoculture treatments, which have effects on heavy metal accumulation. Therefore, further research is needed to investigate organic acids in the intercropping system of $P$. vittata and $S$. alfredii. Additionally, the available As content in $\mathrm{HM}$ rhizosphere soil and that of $\mathrm{Cd}$ in $\mathrm{PH}-\mathrm{H}$ rhizosphere was lower than that from other treatments, which might explain the results of lower As and Cd content in H. spectabile (Table 3).

\subsection{Soil microbial diversity and community structure}

\subsection{1 soil bacterial community diversity}

Generally, intercropping enhanced the soil bacterial community diversity. The bacterial a-diversity indices of ACE, Chao 1 and Shannon in intercropping treatments were significantly more than in SM and HM (Table S2), which could help to maintain the stability of soil microbial structure, indicating that these corresponding species could be intercropped. There were 590 OTUs common to CK and planting treatments (Fig. S1a). The PM, SM and PS treatments shared higher OTUs of 646, and 632 OTUs common to PM, HM, and PH treatments was found (Fig. S1b, S1c). Though the unique OTUs in CK and planting treatments was very low, which from intercropping treatments were higher than monoculture. This agreed with former research that the microbial composition from the intercropping system of $P$. vittata with $M$. alba or B. papyrifera was more complex (Zeng et al., 2019a). Different plant has distinct rhizosphere soil condition due to its own spectrum and specificity of root exudates (Deng et al., 2018). Bian et al. (2021) have found that acetic acid, malic acid, and n-hexadecanoic acid were closely correlated with multiple bacterial species in rhizosphere for intercropping system of Moso bamboo with Sedum plumbizincicola.

\subsubsection{Bacterial community structure}

The phylum Proteobacteria was the dominant bacterial community in all treatments, accounting for 31.0-36.4\% of total phyla in soil (Fig. 3a). The abundance of Proteobacteria was increased in intercropping system compared with monoculture, and that in S. alfredii rhizosphere soil of PS treatment was highest. Similar result has been reported that Proteobacteria predominated in bacterial phyla with more than $31 \%$ relative abundances from intercropping treatment with Moso bamboo and Sedum 
plumbizincicola (Bian et al., 2021). Proteobacteria was important in resistance to metal(loid)s toxicity and significantly correlated with soil nutrients such as carbon, nitrogen, phosphorus contents (Zhang et al., 2016; Zhao et al., 2019). These results suggested that Proteobacteria could help plants increase the environmental quality and intensify the biological function of metal(loid) contaminated soil, in turn the presence of plants could provide a better living condition for microorganisms. Additionally, the other predominant phyla included Actinobacteria, Chloroflexi, Acidobacteria, Bacteroidetes and Gemmatimonadete, which was in consistent with prior research reported by Chen et al. (2018), and they are important for the microbial community reconstruction in metal(loid)-contaminated soil (Zhai et al., 2020).

The genera Massilia, Lysobacter and Sphingomonas, belonging to the phylum Proteobacteria, could adapt to extreme soil conditions (Yang et al., 2019; Jiao et al., 2019). Massilia, Sphingomonas, Lysobacter, arthrobacter and norank_c_Subgroup_6 with an average abundance more than $1 \%$ were the main genera in soil after phytoremediation (Fig. 3b). Lysobacter can resist the pathogens by generating extracellular enzymes and affect the bacterial behaviors (Expósito et al., 2015; Feng et al., 2019), and Massilia could effectively enhance soil P mobilization (Zheng et al., 2017). In the present study, Massilia in S. alfredii rhizosphere soil and Lysobacter in P. vittata rhizosphere soil of PS intercropping system was the richest genus. Zhang et al. (2018) have found that intercropping of Morus alba L. and Medicago sativa L. had a positive impact on bacterial taxa with soil nutrients cycling such as Bacillus, Bradyrhizobium and Sphingomonas as compared to monoculture. The results may be related to that root exudates of different cropping treatments may alter the bacterial community (Li et al., 2016).

\subsection{Relationship between rhizosphere microecological characteristics and phytoextraction efficiency}

The redundancy analysis (RDA) showed that the abundance of Massilia, Arthrobacter and Lysobacter were positively correlated with $\mathrm{NaHCO}_{3}$-As and DTPA-Cd content in rhizosphere soil (Fig. 4a). Moreover, significant correlations were found between the abundance of Massilia and Arthrobacte and Cd content, the abundance of Lysobacter and As content in plant tissues, indicating that they may effectively promote plant $\mathrm{Cd}$ and As uptake (Fig. 4b). This was in accordance with the findings reported by Rojjanateeranaj et al. (2017). Previous studies also have confirmed that some types of microorganisms such as Arthrobater and Bacillus could enhance the phytoremediation efficiency through alleviating metal toxicity to plant (Ma et al., 2016). Therefore, rhizosphere associated microorganisms could play a crucial in regulating phytoremediation, and further studies on the application of the critical genus of microorganisms in phytoremediation with intercropping of $P$. vittata and $S$. alfredii/ $H$. spectabile are warranted.

\section{Conclusions}

Intercropping of $P$. vittata with $S$. alfredii / H. spectabile can effectively alleviate the oxidative stress of As and Cd on plant growth in contaminated soil. The total biomass of $P$. vittata, $S$. alfredii and $H$. spectabile in intercropping systems was significantly improved compared with monoculture by decreasing MDA content and increasing soluble protein content in leaves/pinna. Intercropping of $P$. vittata and $S$. alfredii could simultaneously obtain greater As and Cd accumulation than monoculture and intercropping $P$. vittata with $H$. spectabile. The Venn diagram, heatmap, and RDA analysis showed that the relative abundance of Massilia and Lysobacter in plant rhizosphere were the richest, and significantly correlated with plant Cd and As content from intercropping system of $P$. vittata with $S$. alfredi. Thus, intercropping of $P$. vittata and $S$. alfredii was a promising strategy to simultaneously phytoextract As and Cd co-contaminated soil.

\section{Declarations}

\section{Ethics approval and consent to participate}

Not applicable.

\section{Consent for publication}

Not applicable. 


\section{Availability of data and materials}

All data generated or analysed during this study are included in this published article [and its supplementary information files].

\section{Competing interests}

All authors certify that they have no affiliations with or involvement in any organization or entity with any financial interest or non-financial interest in the subject matter or materials discussed in this manuscript.

\section{Funding}

This work was sponsored by the Environment Production Scientific Research Project of Hunan Province ([2019] 0011) and National Natural Science Foundation of China (Grant No. 41771532), the Fundamental Research Funds for the Central University of Central South University (No. 2019zzts509).

\section{Author contributions}

All authors contributed to the study conception and design. Xiaohui Wang and Cong Zhou: Conceiving and designing the experiments; Xiaohui Wang, Cong Zhou and Xiaoyan Wang: Performing the experiments; Xiaohui Wang and Cong Zhou: Analyzing the data and writing original draft; Xiyuan Xiao, Zhaohui Guo and Chi Peng: reviewing and editing, funding acquisition, project administration. All authors commented on previous versions of the manuscript, and all authors read and approved the final manuscript.

\section{References}

1. Aitken A, Michèle P, Learmonth (2009) Protein determination by UV absorption. The Protein Protocols Handbook. https://doi.org/10.1385/1-59259-169-8:3

2. Antoniadis V, Shaheen SM, Boersch J, Frohne T, Laing GD, Rinklebe J (2017) Bioavailability and risk assessment of potentially toxic elements in garden edible vegetables and soils around a highly contaminated former mining area in Germany. Journal of Environmental Management 186:192-200. https://doi.org/10.1016/j.jenvman.2016.04.036

3. Bedoussac L, Journet EP, Hauggaard-Nielsen H, Naudin C, Corre-Hellou G, Jensen ES, Prieur L, Justes E (2015) Ecological principles underlying the increase of productivity achieved by cereal-grain legume intercrops in organic farming. A review. Agronomy for Sustainable Development 35:911-935. https://doi.org/10.1007/s13593-014-0277-7

4. Bian F, Zhong Z, Zhang X, Yang C (2017) Phytoremediation potential of moso bamboo (Phyllostachys pubescens) intercropped with Sedum plumbizincicola in metal-contaminated soil. Environmental Science Pollution Research 24:27244-27253 https://doi.org/10.1007/s11356-017-0326-2

5. Bian F, Zhong Z, Li C, Zhang X, Gu L, Huang Z, Gai X, Huang Z (2021) Intercropping improves heavy metal phytoremediation efficiency through changing properties of rhizosphere soil in bamboo plantation. Journal of Hazardous Materials 416(62-68):125898. https://doi.org/10.1016/j.jhazmat.2021.125898

6. Cao X, Luo J, Wang X, Chen Z, Liu G, Bilal Khan M, Kang Y, Feng Y, He Z, Yang X (2020) Responses of soil bacterial community and $\mathrm{Cd}$ phytoextraction to a Sedum alfredii-oilseed rape (Brassica napus L. and Brassica juncea L.) intercropping system. Science of the Total Environment 723:138152. https://doi.org/10.1016/j.scitotenv.2020.138152

7. Chen Y, Jiang Y, Huang H, Mou L, Ru J, Zhao J, Xiao S (2018) Long-term and high-concentration heavy-metal contamination strongly influences the microbiome and functional genes in Yellow River sediments. Sci Total Environ 637638:1400-1412 https://doi.org/10.1016/j.scitotenv.2018.05.109

8. Das S, Chou ML, Jean JS, Yang HJ, Kim PJ (2017) Arsenic-enrichment enhanced root exudates and altered rhizosphere microbial communities and activities in hyperaccumulator Pteris vittata. Journal of Hazardous Materials 325:279- 
287 https://doi.org/10.1016/j.jhazmat.2016.12.006

9. Deng S, Ke T, Li L, Cai S, Zhou Y, Liu Y, Guo L, Chen L, Zhang D (2018) Impacts of environmental factors on the whole microbial communities in the rhizosphere of a metal-tolerant plant: Elsholtzia haichowensis Sun. Environ Pollut 237:10881097 https://doi.org/10.1016/j.envpol.2017.11.037

10. Desjardins D, Brereton N, Marchand L, Brisson J, Pitre FE, Labrecque M (2018) Complementarity of three distinctive phytoremediation crops for multiple-trace element contaminated soil. Science of the Total Environment. 610-611, 1428 https://doi.org/10.1016/j.scitotenv.2017.08.196

11. Du J, Guo Z, Li R, Ali A, Guo D, Lahori AH, Wang P, Liu X, Wang X, Zhang Z (2020) Screening of Chinese mustard (Brassica juncea $\mathrm{L}$.) cultivars for the phytoremediation of $\mathrm{Cd}$ and $\mathrm{Zn}$ based on the plant physiological mechanisms. Environmental Pollution 261:114-213 https://doi.org/10.1016/j.envpol.2020.114213

12. Expósito R, Postma J, Raaijmakers JM, Bruijn ID (2015) Diversity and activity of Lysobacter species from disease suppressive soils. Frontiers in Microbiology 6(145):1243 https://doi.org/10.3389/fmicb.2015.01243

13. Feng T, Han Y, Li B, Li Z, Yu Y, Sun Q, Li X, Du L, Zhang X, Wang Y (2019) Interspecies and intraspecies signals synergistically regulate Lysobacter enzymogenes twitching motility. Genetics Molecular Biology 85(23):e01742-e01719. https://doi.org/10.1128/AEM.01742-19

14. Guo Y, Qiu C, Long S, Wang H, Wang Y (2020) Cadmium accumulation, translocation, and assessment of eighteen Linum usitatissimum L. cultivars growing in heavy metal contaminated soil. International journal of phytoremediation 22:490496 https://doi.org/10.1080/15226514.2019.1683714

15. Hong Y, Heerink N, Jin S, Berentsen P, Zhang L, Werf W (2017) Intercropping and agroforestry in China - current state and trends. Agriculture Ecosystems Environment 244:52-61. https://doi.org/10.1016/j.agee.2017.04.019

16. Huang M, Zhu Y, Li ZW, Huang B, Luo NL, Liu C, Zeng GM (2016) Compost as a soil amendment to remediate heavy metalcontaminated agricultural soil: mechanisms, efficacy, problems, and strategies. Water Air Soil Pollut 227. https://doi.org/10.1007/s11270-016-3068-8

17. January MC, Cutright TJ, Keulen HV, Wei R (2008) Hydroponic phytoremediation of Cd, Cr, Ni, As, and Fe: can Helianthus annuus hyperaccumulate multiple heavy metals? Chemosphere 70(3):531-537.

https://doi.org/10.1016/j.chemosphere.2007.06.066

18. Jiao S, Xu Y, Zhang J, Hao X, Lu Y (2019) Core microbiota in agricultural soils and their potential associations with nutrient cycling. Msystems 4:e00313-e00318 https://doi.org/10.1128/mSystems.00313-18

19. Kim J, Lee Y, Chung J (2013) The role of organic acids in the mobilization of heavy metals from soil. Ksce Journal of Civil Engineering 17(7):1596-1602. https://doi.org/10.1007/s12205-013-0323-z

20. Kumar S, Prasad S, Yadav KK, Shrivastava M, Malav L (2019) Hazardous heavy metals contamination of vegetables and food chain: role of sustainable remediation approaches - a review. Environ Res 179:108792. https://doi.org/10.1016/j.envres.2019.108792

21. Li Q, Wu L, Chen J, Khan MA, Luo X, Lin W (2016) Biochemical and microbial properties of rhizospheres under maize/peanut intercropping. Journal of Integrative Agriculture 15:101-110. https://doi.org/10.1016/S20953119(15)61089-9

22. Li Z, Wang J, An L, Tan J, Zhan F, Wu J, Zu Y (2019) Effect of root exudates of intercropping Vicia faba and Arabis alpina on accumulation and sub-cellular distribution of lead and cadmium. International Journal of Phytoremediation. 21, 413 https://doi.org/10.1080/15226514.2018.1523867

23. Liang Y, Wang X, Guo Z, Xiao X, Peng C, Yang J, Zhou C, Zeng P (2019) Chelator-assisted phytoextraction of arsenic, cadmium and lead by Pteris vittata $\mathrm{L}$. and soil microbial community structure response. International journal of phytoremediation 21:1032-1040. https://doi.org/10.1080/15226514.2019.1594685

24. Liang Y, Xiao X, Guo Z, Peng C, Zeng P, Wang X (2021) Co-application of indole-3-acetic acid/gibberellin and oxalic acid for phytoextraction of cadmium and lead with sedum alfredii hance from contaminated soil. Chemosphere

285:131420 https://doi.org/10.1016/j.chemosphere.2021.131420

Page 9/15 
25. Lin L, Chen F, Wang J, Liao M, Lv X, Wang Z, Li H, Deng Q, Xia H, Liang D, Tang Y, Wang X, Lai Y, Ren W (2018) Effects of living hyperaccumulator plants and their straws on the growth and cadmium accumulation of Cyphomandra betacea seedlings. Ecotoxicology and Environmental Safety. 155, 109-116. https://doi.org/10.1016/j.ecoenv.2018.02.072

26. Lindsay WL, Norvell WA (1978) Development of a DTPA soil test for zinc, iron, manganese, and copper. Soil Science Society of America Journal 42:421-428 https://doi.org/10.2136/sssaj1978.03615995004200030009x

27. Lu K (2000) Analytical Methods of Soil Agricultural Chemistry. Beijing

28. Ma J, Lei E, Lei M, Liu Y, Chen T (2018) Remediation of arsenic contaminated soil using malposed intercropping of Pteris vittata L. and maize. Chemosphere 194:737-744 https://doi.org/10.1016/j.chemosphere.2017.11.135

29. Ma L, Wu Y, Wang Q, Feng Y (2020) The endophytic bacterium relieved healthy risk of pakchoi intercropped with hyperaccumulator in the cadmium polluted greenhouse vegetable field. Environmental Pollution 264:114796. https://doi.org/10.1016/j.envpol.2020.114796

30. Ma Y, Rajkumar M, Zhang C, Freitas H (2016) Beneficial role of bacterial endophytes in heavy metal phytoremediation. Journal of Environmental Management 174:14-25 http://dx.doi.org/10.1016/j.jenvman.2016.02.047

31. Mahar A, Wang P, Ali A, Awasthi MK, Lahori AH, Wang Q, Li R, Zhang Z (2016) Challenges and opportunities in the phytoremediation of heavy metals contaminated soils: A review. Ecotoxicol Environ Saf 126:111$121 \mathrm{https} / / /$ doi.org/10.1016/j.ecoenv.2015.12.023

32. Moffett JR, Price RA, Anderson SM, Sipos ML, Moran AV, Tortella FC, Dave JR (2003) DNA fragmentation in leukocytes following subacute low-dose nerve agent exposure. Cellular Molecular Life Sciences 60:2266-2271. https://doi.org/10.1007/s00018-003-3238-x

33. Mu T, Wu T, Zhou T, Li Z, Ouyang Y, Jiang J, Zhu D, Hou J, Wang Z, Luo Y, Christie P, Wu L (2019) Geographical variation in arsenic, cadmium, and lead of soils and rice in the major rice producing regions of China. Science of The Total Environment 677:373-381 https://doi.org/10.1016/j.scitotenv.2019.04.337

34. Pan G, Liu W, Zhang H, Liu P (2018) Morphophysiological responses and tolerance mechanisms of Xanthium strumarium to manganese stress. Ecotoxicology Environmental Safety 165:654-661. https://doi.org/10.1016/j.ecoenv.2018.08.107

35. Patra DK, Pradhan C, Patra HK (2020) Toxic metal decontamination by phytoremediation approach: Concept, challenges, opportunities and future perspectives. Environmental Technology Innovation 18:100672. https://doi.org/10.1016/j.eti.2020.100672

36. Reeves RD, Baker A, Jaffré T, Erskine PD, Echevarria G, Ent A (2017) A global database for plants that hyperaccumulate metal and metalloid trace elements. New Phytologist 218:407-411. https://doi.org/10.1111/nph.14907

37. Rojjanateeranaj P, Chirawee S, Prapagdee B (2017) Enhanced cadmium phytoremediation of Glycine max L. through bioaugmentation of cadmium-resistant bacteria assisted by biostimulation. Chemosphere 185:764771 https://doi.org/10.1016/j.chemosphere.2017.07.074

38. Tang Y, He J, Yu X, Xie Y, Lin L, Sun G, Li H, Liao M, Liang D, Xia H, Wang X, Zhang J, Liu Z, Tu L, Liu L (2017) Intercropping with Solanum nigrum and Solanum photeinocarpum from two ecoclimatic regions promotes growth and reduces cadmium uptake of eggplant seedlings. Pedosphere. 3, 638-644. https://doi.org/10.1016/S1002-0160(17)60358-8

39. Tao Q, Hou D, Yang X, Li T (2016) Oxalate secretion from the root apex of Sedum alfredii contributes to hyperaccumulation of Cd. Plant Soil 398:139-152 https://doi.org/10.1007/s11104-015-2651-x

40. Velikova V, Yordanov I, Edreva A (2000) Oxidative stress and some antioxidant systems in acid rain-treated bean plants: Protective role of exogenous polyamines. Plant Science 151:59-66 https://doi.org/10.1016/S0168-9452(99)00197-1

41. Wan X, Lei M (2018) Intercropping efficiency of four arsenic hyperaccumulator Pteris vittata populations as intercrops with Morus alba. Environmental Science Pollution Research 25:12600-12611. https://doi.org/10.1007/s11356-018-1366-y

42. Wan X, Lei M, Chen T, Yang J (2017) Intercropped Pteris vittata L. and Morus alba L. presents a safe utilization mode for arsenic-contaminated soil. Sci Total Environ 579:1467-1475. https://doi.org/10.1016/j.scitotenv.2016.11.148

43. Wan X, Lei M, Yang J, Chen T (2020) Three-year field experiment on the risk reduction, environmental merit, and cost assessment of four in situ remediation technologies for metal(loid)-contaminated agricultural soil. Environmental Pollution 
266:115193 https://doi.org/10.1016/j.envpol.2020.115193

44. Wang R, Xiao Y, Lv F, Hu L, Wei L, Yuan Z, Lin H (2018) Bacterial community structure and functional potential of rhizosphere soils as influenced by nitrogen addition and bacterial wilt disease under continuous sesame cropping. Applied Soil Ecology 125:117-127 https://doi.org/10.1016/j.apsoil.2017.12.014

45. WHO (2017) World Health Organization. WHO) International Agency for research on cancer carcinogens list

46. Woolson EA, Axley JH, Kearney PC (1971) Correlation between available soil arsenic, estimated by six methods, and response of corn (Zea mays L.). Soil Science Society of America Journal 35:101-105. https://doi.org/10.2136/sssaj1971.03615995003500010030x

47. Xia H, Liang D, Chen F, Liao M, Lin L, Tang Y, Lv X, Li H, Wang Z, Wang X, Wang J, Liu L, Ren W (2018) Effects of mutual intercropping on cadmium accumulation by the accumulator plants Conyza canadensis, Cardamine hirsuta, and Cerastium glomeratum. International Journal of Phytoremediation. 20, 855-861 https://doi.org/10.1080/15226514.2018.1438356

48. Xiao X, Chen T, An Z, Lei M, Huang Z, Liao X, Liu Y (2008) Potential of Pteris vittata L. for phytoremediation of sites cocontaminated with cadmium and arsenic: The tolerance and accumulation. Journal of Environmental Sciences 20:6267 https://doi.org/10.1016/S1001-0742(08)60009-1

49. Yang E, Cui D, Wang W (2019) Research progress on the genus Massilia. Microbiology China 46(6):1537-1548. https://doi.org/10.13344/j.microbiol.china.180573

50. Yang J, Guo J, Yang J (2018) Cadmium accumulation and subcellular distribution in populations of Hylotelephium spectabile (Boreau) H. Ohba. Environmental Science Pollution Research 25:30917-30927.

https://doi.org/10.1007/s11356-018-3065-0

51. Yang J, Yang J, Huang J (2017) Role of co-planting and chitosan in phytoextraction of As and heavy metals by Pteris vittata and castor bean - A field case. Ecological Engineering 109:35-40. https://doi.org/10.1016/j.ecoleng.2017.09.001

52. Yang M, Xiao X, Miao X, Guo Z, Wang F (2012) Effect of amendments on growth and metal uptake of giant reed (Arundo donax L.) grown on soil contaminated by arsenic, cadmium and lead. Transactions of Nonferrous Metals Society of China 22:1462-1469 https://doi.org/10.1016/S1003-6326(11)61342-3

53. Yang Q, Li Z, Lu X, Duan Q, Huang L, Bi J (2018) A review of soil heavy metal pollution from industrial and agricultural regions in China: Pollution and risk assessment. Science of the Total Environment 642:690-700. https://doi.org/10.1016/j.scitotenv.2018.06.068

54. Yang X, Li T, Yang J, He Z, Lu L, Meng F (2006) Zinc compartmentation in root, transport into xylem, and absorption into leaf cells in the hyperaccumulating species of Sedum alfredii Hance. Planta 224:85-195. https://doi.org/10.1007/s00425005-0194-8

55. Yang X, Long X, Ye H, He Z, Calvert DV, Stoffella PJ (2004) Cadmium tolerance and hyperaccumulation in a new Znhyperaccumulating plant species (Sedum alfredii Hance). Plant soil 259:181-189.

https://doi.org/10.1023/B:PLS0.0000020956.24027.f2

56. Yu HY, Ding X, Li F, Wang X, Zhang S, Yi J, Liu C, Xu X, Wang Q (2016) The availabilities of arsenic and cadmium in rice paddy fields from a mining area: the role of soil extractable and plant silicon. Environmental Pollution 215:258265 https://doi.org/10.1016/j.envpol.2016.04.008

57. Zeng P, Guo Z, Xiao X, Peng C (2019a) Effects of tree-herb co-planting on the bacterial community composition and the relationship between specific microorganisms and enzymatic activities in metal(loid)-contaminated soil. Chemosphere 220:237-248 https://doi.org/10.1016/j.chemosphere.2018.12.073

58. Zeng P, Guo Z, Xiao X, Peng C, Feng W, Xin L, Xu Z (2019b) Phytoextraction potential of Pteris vittata L. co-planted with woody species for $\mathrm{As}, \mathrm{Cd}, \mathrm{Pb}$ and $\mathrm{Zn}$ in contaminated soil. Science of the Total Environment 650:594603 https://doi.org/10.1016/j.scitotenv.2018.09.055

59. Zhai W, Dai Y, Zhao W, Yuan H, Qiu D, Chen J, Gustave W, Maguffin SC, Chen Z, Liu X, Tang X, Xu J (2020) Simultaneous immobilization of the cadmium, lead and arsenic in paddy soils amended with titanium gypsum. Environmental Pollution 258:113790 https://doi.org/10.1016/j.envpol.2019.113790

Page $11 / 15$ 
60. Zhang C, Liu G, Xue S, Wang G (2016) Soil bacterial community dynamics reflect changes in plant community and soil properties during the secondary succession of abandoned farmland in the Loess Plateau. Soil Biology Biochemistry 97:40-49 https://doi.org/10.1016/j.soilbio.2016.02.013

61. Zhang M, Wang N, Hu Y, Sun G (2018) Changes in soil physicochemical properties and soil bacterial community in mulberry (Morus alba L.)/alfalfa (Medicago sativa L.) intercropping system. MicrobiologyOpen7(2): e555.

https://doi.org/10.1002/mbo3.555

62. Zhao F, Ma Y, Zhu Y, Tang Z, McGrath SP (2015) Soil contamination in China: Current status and mitigation strategies. Environmental Science Technology 49:750-759 https://doi.org/10.1021/es5047099

63. Zhao X, Huang J, Lu J, Sun Y (2019) Study on the influence of soil microbial community on the long-term heavy metal pollution of different land use types and depth layers in mine. Ecotoxicology Environmental Safety 170:218226 https://doi.org/10.1016/j.ecoenv.2018.11.136

64. Zheng B, Bi Q, Hao X, Zhou G, Yang X (2017) Massilia phosphatilytica sp. nov., a phosphate solubilizing bacteria isolated from a long-term fertilized soil. Int J Syst Evol Microbiol 67(8):2514-2519 https://doi.org/10.1099/ijsem.0.001916

65. Zhou C, Xiao X, Guo Z, Peng C, Zeng P, Bridget FA (2020) Physiological responses, tolerance efficiency, and phytoextraction potential of Hylotelephium spectabile (Boreau) $\mathrm{H}$. Ohba under $\mathrm{Cd}$ stress in hydroponic condition. Int J Phytoremediation 23:1-9. https://doi.org/10.1080/15226514.2020.1797628

66. Zu Y, Qin L, Zhan F, Wu J, Li Y, Chen J, Wang J, Hu W (2020) Intercropping of Sonchus asper and Vicia faba affects plant cadmium accumulation and root responses. Pedosphere 30:457-465. https://doi.org/10.1016/S1002-0160(17)60484-3

\section{Tables}

Table 1

The content of MDA and soluble protein in leaves (pinna for P. vittata) of plants from monoculture and intercropping treatments

\begin{tabular}{|c|c|c|c|}
\hline Plants & Treatments & MDA content (nmol/g FW) & soluble protein content (mg/g FW) \\
\hline \multirow[t]{3}{*}{ P. vittata } & PM & $7.52 \pm 0.47 a$ & $10.6 \pm 0.80 c$ \\
\hline & PS & $6.37 \pm 0.16 b$ & $11.0 \pm 0.37 b$ \\
\hline & $\mathrm{PH}$ & $6.22 \pm 0.55 b$ & $12.4 \pm 1.00 a$ \\
\hline \multirow[t]{2}{*}{ S. alfredii } & SM & $1.01 \pm 0.01 a$ & $4.65 \pm 0.27 a$ \\
\hline & PS & $1.06 \pm 0.08 a$ & $4.59 \pm 0.49 a$ \\
\hline \multirow[t]{2}{*}{ H. spectabile } & $\mathrm{HM}$ & $2.04 \pm 0.33 a$ & $4.60 \pm 0.38 a$ \\
\hline & $\mathrm{PH}$ & $1.98 \pm 0.07 a$ & $4.48 \pm 0.96 a$ \\
\hline
\end{tabular}

Different letters within the same column indicate significant differences $(P<0.05)$ between the intercropping treatment and corresponding monoculture. Values are shown as means $\pm \operatorname{SD}(n=4)$.

Table 2 The As, Cd content and transfer factor in P. vittata, S. alfredii, H. spectabile from monoculture and intercropping treatments 


\begin{tabular}{|c|c|c|c|c|c|c|c|}
\hline \multirow[t]{2}{*}{ Plants } & \multirow[t]{2}{*}{ Treatments } & \multicolumn{2}{|c|}{$\begin{array}{l}\text { Root (rhizoid) content } \\
\left(\mathrm{mg} \cdot \mathrm{kg}^{-1}\right)\end{array}$} & \multicolumn{2}{|c|}{$\begin{array}{l}\text { Shoot (frond) content } \\
\left(\mathrm{mg} \cdot \mathrm{kg}^{-1}\right)\end{array}$} & \multicolumn{2}{|c|}{$\begin{array}{l}\text { Transfer factor } \\
\text { (TF } \\
\text { shoot(frond)/root(rhizoid) })\end{array}$} \\
\hline & & As & $\mathrm{Cd}$ & As & $\mathrm{Cd}$ & As & $\mathrm{Cd}$ \\
\hline \multirow[t]{3}{*}{ P. vittata } & PM & $191 \pm 5.89 c$ & $1.75 \pm 0.35 a$ & $1125 \pm 118 \mathrm{c}$ & $0.50 \pm 0.20 \mathrm{a}$ & $5.89 \pm 0.61 a$ & $0.31 \pm 0.13 a$ \\
\hline & PS & $245 \pm 34.7 a$ & $2.00 \pm 0.04 a$ & $1339 \pm 63.0 \mathrm{a}$ & $0.33 \pm 0.13 a$ & $5.47 \pm 0.70 a$ & $0.29 \pm 0.00 a$ \\
\hline & $\mathrm{PH}$ & $213 \pm 32.4 b$ & $1.41 \pm 0.12 \mathrm{a}$ & $1248 \pm 171 b$ & $0.44 \pm 0.11 a$ & $5.85 \pm 0.74 a$ & $0.30 \pm 0.10 a$ \\
\hline \multirow[t]{2}{*}{ S. alfredii } & SM & $19.5 \pm 1.14 a$ & $286 \pm 33.7 b$ & $3.16 \pm 1.20 \mathrm{a}$ & $362 \pm 51.8 b$ & $0.16 \pm 0.06 a$ & $1.26 \pm 0.18 a$ \\
\hline & PS & $19.0 \pm 0.53 a$ & $324 \pm 60.1 a$ & $2.90 \pm 0.77 a$ & $416 \pm 60.4 a$ & $0.21 \pm 0.03 a$ & $1.31 \pm 0.27 a$ \\
\hline \multirow{2}{*}{$\begin{array}{l}\text { H. } \\
\text { spectabile }\end{array}$} & $\mathrm{HM}$ & $23.5 \pm 2.26 a$ & $5.18 \pm 0.71 a$ & $4.07 \pm 0.23 b$ & $14.7 \pm 3.46 a$ & $0.21 \pm 0.10 \mathrm{a}$ & $2.58 \pm 0.31 a$ \\
\hline & $\mathrm{PH}$ & $21.7 \pm 2.32 \mathrm{a}$ & $4.43 \pm 1.15 b$ & $5.49 \pm 1.13 a$ & $11.9 \pm 3.25 b$ & $0.25 \pm 0.04 a$ & $2.33 \pm 0.58 a$ \\
\hline
\end{tabular}

Different letters within the same column indicate significant differences $(P<0.05)$ between the intercropping treatment and corresponding monoculture. Values are shown as means $\pm \operatorname{SD}(n=4)$.

Table 3

Arsenic and $\mathrm{Cd}$ accumulation in plants under monoculture and intercropping treatments

\begin{tabular}{|llll|}
\hline Plant & Treatments & \multicolumn{2}{l|}{ Heavy metal accumulation $\left(\mu \mathrm{g} \bullet\right.$ plant $\left.^{-1}\right)$} \\
\cline { 2 - 4 } & & As & Cd \\
\hline P. vittata & PM & $772 \pm 90.3 \mathrm{c}$ & $1.17 \pm 0.29 \mathrm{a}$ \\
\cline { 2 - 4 } & PS & $953 \pm 163 \mathrm{~b}$ & $0.93 \pm 0.13 \mathrm{a}$ \\
\cline { 2 - 4 } & $\mathrm{PH}$ & $984 \pm 84.3 \mathrm{a}$ & $1.30 \pm 0.33 \mathrm{a}$ \\
\hline S. alfredii & $\mathrm{SM}$ & $3.06 \pm 0.23 \mathrm{a}$ & $151 \pm 15.4 \mathrm{~b}$ \\
& $\mathrm{PS}$ & $3.22 \pm 0.13 \mathrm{a}$ & $173 \pm 9.81 \mathrm{a}$ \\
\hline H. spectabile & $\mathrm{HM}$ & $8.06 \pm 1.17 \mathrm{~b}$ & $8.14 \pm 1.30 \mathrm{a}$ \\
\cline { 2 - 4 } & $\mathrm{PH}$ & $10.1 \pm 1.80 \mathrm{a}$ & $8.22 \pm 1.81 \mathrm{a}$ \\
\cline { 2 - 4 } & &
\end{tabular}

Different letters within the same column indicate significant differences $(P<0.05)$ between the intercropping treatment and corresponding monoculture. Values are shown as means $\pm \operatorname{SD}(n=4)$.

\section{Figures}



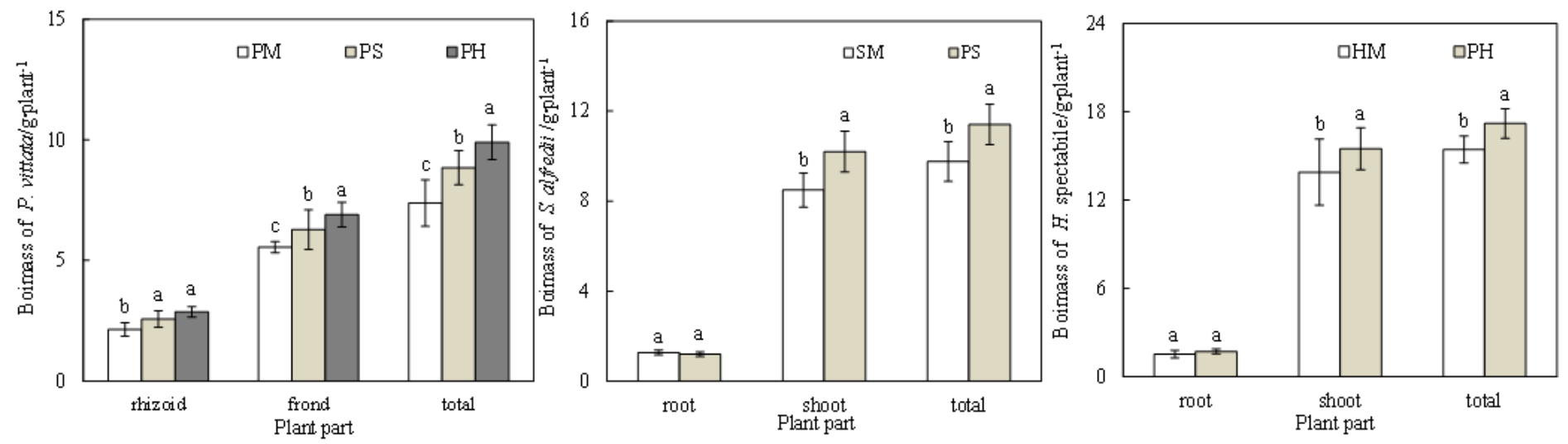

Figure 1

Biomass of P. vittata, S. alfredii and $\mathrm{H}$. spectabile from monoculture and intercropping treatments
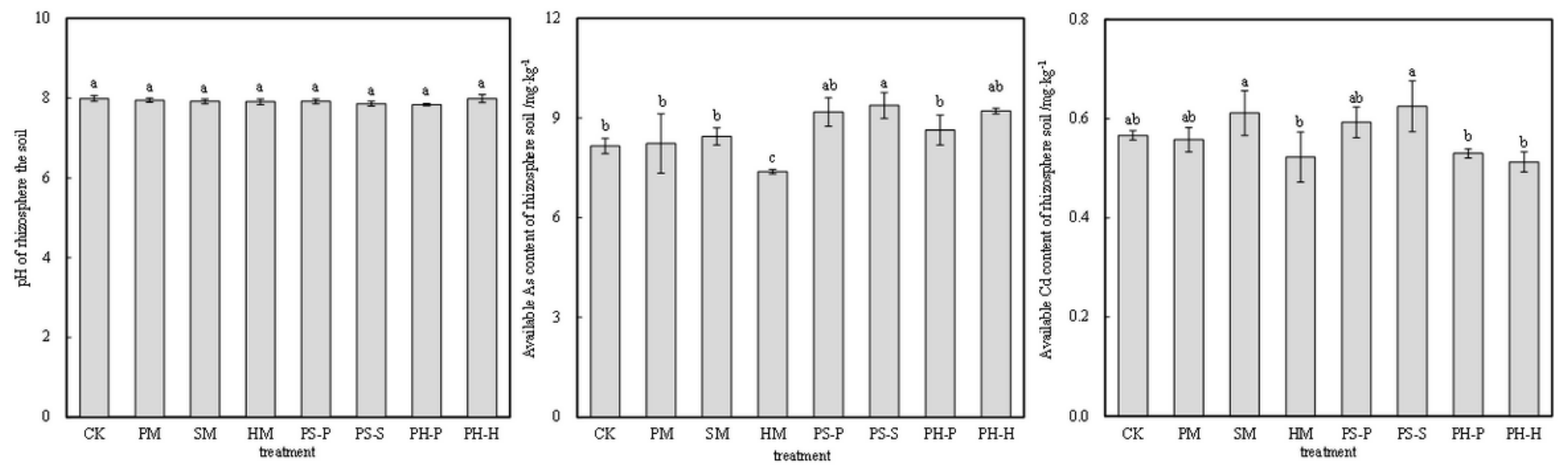

Figure 2

Soil pH, available As and $\mathrm{Cd}$ content in rhizosphere soil after phytoremediation under different treatments.

(a)

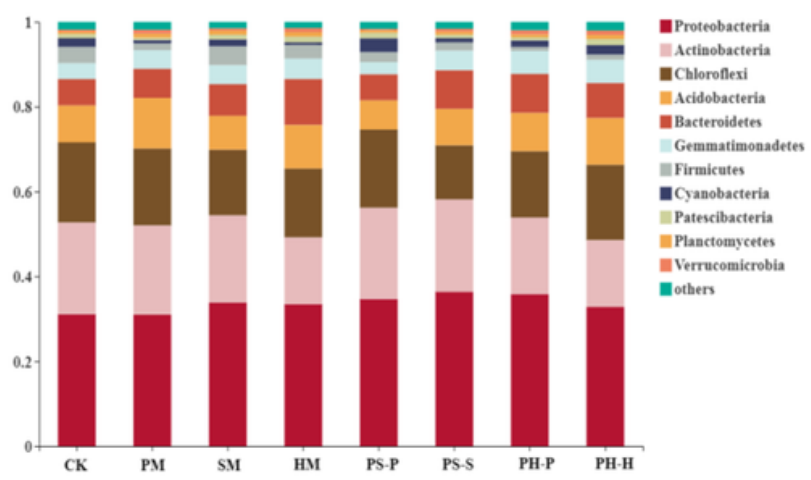

(b)

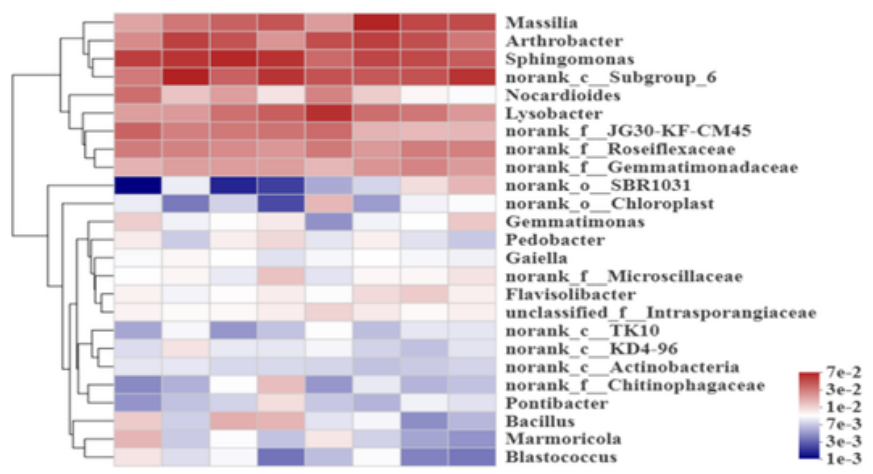

CK PM SM HM PS-P PS-S PH-P PH-H

Figure 3

Soil bacterial taxonomic distribution: relative abundance of predominant phyla (a) and community heatmap analysis at genus level (b) under different treatments. 


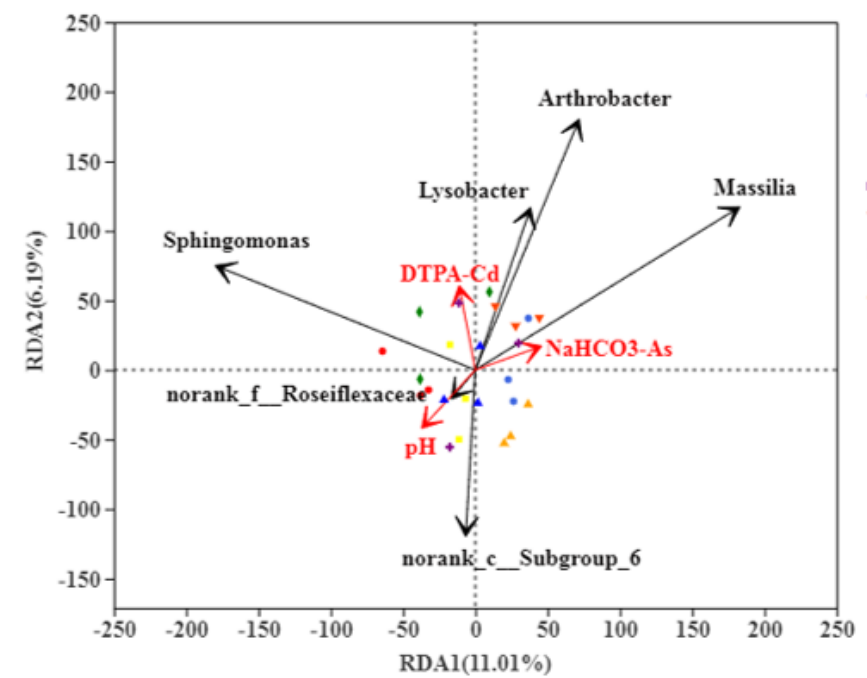

(a)

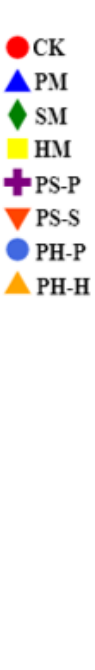

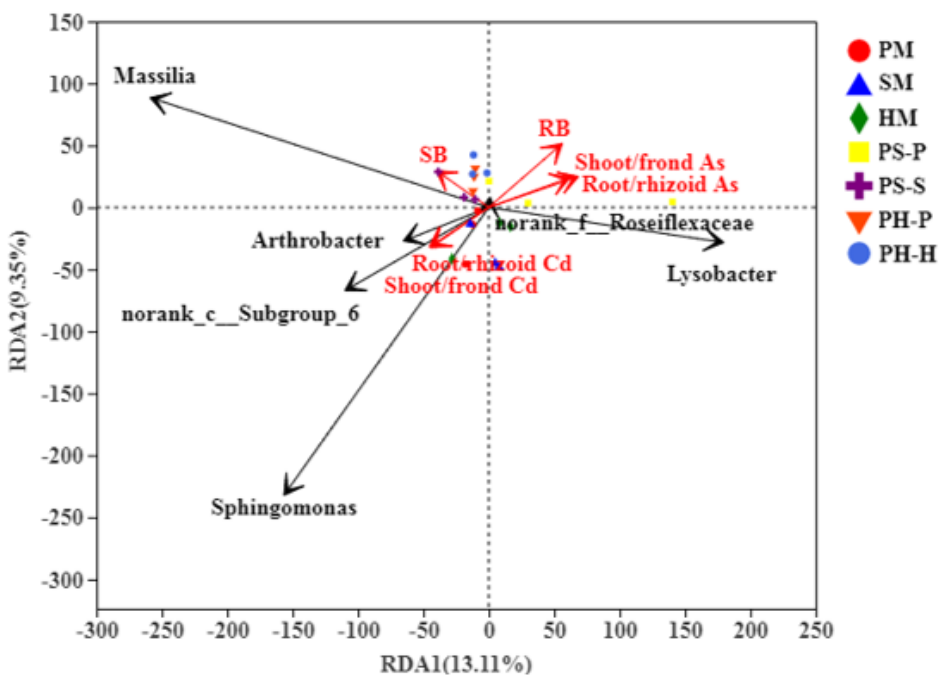

(b)

\section{Figure 4}

(a) Redundancy analysis (RDA) of the soil pH, available As and Cd content and bacterial communities at genus level, (b) RDA of the phytoremediation parameters and bacterial communities at genus level. NaHCO3-As, soli available As content; DTPA-Cd, soli available Cd content; SB, shoot/frond biomass; RB, root/rhizoid biomass; Shoot/frond As, As content in shoot/frond; Shoot/frond Cd, Cd content in shoot/frond; Root/rhizoid As, As content in root/rhizoid; Root/rhizoid Cd, Cd content in root/rhizoid.

\section{Supplementary Files}

This is a list of supplementary files associated with this preprint. Click to download.

- Supplementarymaterial.docx 